\title{
TARBP2 Gene
}

National Cancer Institute

\section{Source}

National Cancer Institute. TARBP2 Gene. NCI Thesaurus. Code C84407.

This gene plays a role in both translational silencing and viral infection. 